Przegląd Badań Edukacyjnych Educational Studies Review

ISSN 1895-4308

nr 19 (2/2014), s. 81-96

METAANALIZY

BADAŃ

EDUKACYJNYCH

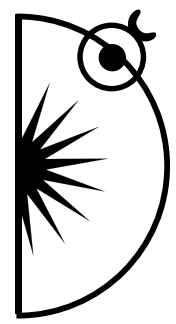

Marzenna Zaorska

Uniwersytet Warmińsko-Mazurski, e-mail: mzaorska@poczta.onet.pl

\title{
Pozoranctwo/pozorność/pozory/pozór w działaniach na rzecz osób niepełnosprawnych
}

DOI: http://dx.doi.org/10.12775/PBE.2014.023

\section{Shamming Helpful Actions for the Handicapped}

\begin{abstract}
Specialised actions realised for handicapped people can be analysed in many different aspects and dimensions. They do not only apply to the structure, aim, content, addressee, methods, forms, means and conditions of conducting multi-frequency and interdisciplinary support to a handicapped person, but also highly important elements of that person's own evaluation and effectiveness. The effectiveness of special help aimed at the handicapped validates itself in that person achieving self-reliance, social and individual maturity, high quality of life in all periods of personal development and self-fulfilment. The highlighted effectiveness consists of many factors that are rooted both in the handicapped person's personality and environment. These factors can help, but they can also hinder achieving the goals that have been set. One of the factors that hinder the process of aiding a handicapped person is the phenomenon of shamming specialised help, which can be present both in the behaviour of specialists, people from the handicapped person's environment and in the system, concept, and legal solutions. Consequently, the article elaborates on the selected problems related to shamming common social activity addressed to people experiencing the consequences of disability, which is understood in basic categories, that is without going into specifics of a particular type of disability.
\end{abstract}

Key words: shamming, disability, handicapped person, special pedagogy, helpful actions towards disabled people, education, rehabilitation, development aid 


\section{Wprowadzenie}

Podejmując dyskurs na temat szeroko ujętego zagadnienia pozoru w pedagogice specjalnej (jako efektu pozoranctwa, pozorności i pozorów), w odniesieniu do kwestii zarówno teoretycznych, jak i praktycznych, należy przede wszystkim zasugerować dwie możliwe, ale wzajemnie ze sobą połączone i wzajemnie siebie przenikające płaszczyzny analizy eksponowanego zagadnienia. Pierwszą jest płaszczyzna terminologiczno-koncepcyjna, drugą zaś płaszczyzna faktycznie realizowanych działań specjalistycznych, ukierunkowanych na ich rzeczywisty i nadrzędny podmiot.

Wobec powyższego można zadać pytanie, a właściwie pytania, o istotę hipotetycznie możliwą interpretację terminu ,pozór” oraz skorelowanych z nim terminów „pozoranctwo”, ,pozorność”, ,pozory”, jak również o wzajemne powiązania pomiędzy tymi określeniami.

W słownikach języka polskiego znajdujemy odniesienie terminu ,pozór” do określenia „pozowanie”, gdzie pozowanie oznacza nie tylko przybieranie jakiejś pozy lub udawanie kogoś innego niż się jest w rzeczywistości, ale również sztuczne, nienaturalne zachowanie, niebycie sobą. Sformułowanie ,pozór” oznacza więc łudzące, mylne powierzchowne wrażenie o czymś lub o kimś, albo typ działań w istocie swej wyglądających zupełnie inaczej niż rzeczywiście są przy ich bezpośrednim i powierzchownym odbiorze, tj. działań złudnych, fałszywych, niesłużących pokazaniu prawdziwości w prezentowanym sposobie myślenia, artykułowanych intencjach czy realizowanych zachowaniach (Szymczak, 1987, s. 891).

Pozowanie zachowań wiąże się też bezpośrednio z pojęciem pozy w rozumieniu pozy nienaturalnej, sztucznej, przesadnej, ze sposobem bycia polegającym na udawaniu czegoś lub kogoś, manieryzmem oraz afektacją, gdzie afektacja definiowana jest jako przesadne i nieprawdziwe zachowywanie się (Tokarski, 1978, s. 9). Oznacza to, że w zachowaniach pozowanych, a szczególnie w odbiorze przez innych takich zachowań można wyróżnić elementy: percepcyjno-recepcyjny, interocepcyjny, behawioralny oraz mentalno-działaniowy:

- element percepcyjno-recepcyjny wiąże się z bezpośrednim postrzeganiem (percepcją oraz recepcja) postaw, zachowań, deklaracji werbalnych składanych przez osobę lub grupę osób w kontekście przyjęcia ich za prawdziwe, podania w wątpliwość lub odrzucenia jako nieprawdziwe w sposób oficjalny i bezpośrednio demonstrowany albo odrzucenia ukrytego, tzn. pozostawienia wiedzy na ich temat wyłącznie do własnej, indywidualnej wiadomości; 
- element interocepcyjny dotyczy przyjęcia postaw, zachowań, deklaracji werbalnych składanych przez osobę lub grupę osób za pozorowane, ukrywające rzeczywiste intencje na zasadzie wewnętrznego przekonania, że takimi właśnie są, i nie bacząc na zapewniania składane przez osobę lub grupę osób wykazującą lub wykazujących pozowanie, iż jest inaczej niż my o niej lub o nich myślimy;

- element behawioralny to sposób (werbalny - słowny i niewerbalny w postaci mimiki, pantomimiki, gestów i postaw ciała), w jaki informujemy osobę lub grupę osób wykazującą lub wykazujących pozowanie, że odczytujemy ich słowa, składane deklaracje, realizowane zachowanie/zachowania jako niepokazujące rzeczywistych intencji, ukrywające prawdziwe ich oblicze czy jako zachowanie/zachowania, któremu/ którym trudno dać wiarę, że są adekwatne do faktycznych odczuć lub poglądów;

- element mentalno-dzialaniowy to utrwalony w osobie sposób percepcji, recepcji, myślenia i zachowania się wobec ludzi pozujących prezentowane przez siebie postawy, zachowania, składane deklaracje werbalne wobec osoby lub osób pod adresem, której/których są one kierowane.

Wracając jednak do określeń zasygnalizowanych w tytule niniejszego tekstu, należy podjąć się ich interpretacji tak, by tworzyła ona możliwość jej przeniesienia na działania realizowane wobec osób z niepełnosprawnością oraz środowisk ich indywidualnego życia i codziennej egzystencji. I tak pozoranctwo należy rozumieć jako sposób zachowania się lub działania stwarzający wrażenie sztuczności, nieprawdziwości, nienaturalności, udawania dobrych intencji. Pozorność z kolei to ukierunkowanie realizowanych działań z celowością pozorowania ich faktycznych intencji, tj. pozorowany sposób zachowania lub działania z nakierowaniem na cel lub cele pozorny/pozorne, tj. sztuczne, nieprawdziwe, nienaturalne, $z$ udawaniem dobrych intencji. Pozory natomiast to efekty pozorności, a co za tym idzie również pozoranctwa, tzn. efekty sprawiające nierzeczywiste i ukrywane wrażenie dobrych intencji wobec podmiotu lub podmiotów, wobec których owe pozornie dobre intencje są kierowane. Pozór jako pojęcie globalne, najbardziej ogólne w porównaniu z pojęciami już zdefiniowanymi, to ogólny, a właściwie ogólnospołeczny efekt pozorów zbudowanych z pozoranctwa egzemplifikującego się w postaci pozorności.

Analogie dotyczące zachowań pozowanych w postaci pozoranctwa, pozorności, pozorów oraz pozoru można przenieść na wspomniane wyżej płaszczyzny funkcjonowania pedagogiki specjalnej jako dyscypliny teoretycznej i praktycznej, tzn. na płaszczyznę terminologiczno-koncepcyjną oraz faktycznie 
realizowanych działań specjalistycznych ukierunkowanych na ich rzeczywisty i nadrzędny podmiot, $\mathrm{tj}$. osobę $\mathrm{z}$ niepełnosprawnością.

Podsumowując część rozważań na temat istoty zachowań pozorowanych, warto przywołać sentencję autorstwa Françoisa de La Rochefoucaulda: „Prawda nie sprawia tyle dobrego, ile złego sprawiaja jej pozory" (de La Rochefoucauld, 1951, s. 18).

\section{Pozoranctwo/pozorność/pozory/pozór w koncepcyjno- -terminologicznej płaszczyźnie działań na rzecz osób niepełnosprawnych}

Analizując zagadnienie pozoranctwa oraz jego korelatów w postaci pozorności, pozorów i pozoru w płaszczyźnie koncepcyjno-terminologicznej, należy przede wszystkim wymienić te czynniki, które do ich obecności przyczyniają się. A są nimi m.in.: niedoprecyzowanie, ogólność (ogólnikowość wręcz), rozpływalność. Ich efektem natomiast są lub mogą być: wielość interpretacji (co nie oznacza różnorodność interpretacji i odmienność podejść w nich zawartą), niedo- lub nadinterpretacja postulowanych kontekstów i ujęć, możliwe ukryte sugestie oraz ukierunkowanie na maskowanie faktycznego stanu rzeczy.

Teraz czas na bardziej konkretne odniesienia i przykłady. Wprowadzona, na tle krytyki medycznego podejścia do stanu ludzkiej niepełnosprawności, w roku 1980, Międzynarodowa Klasyfikacja Uszkodzeń, Niepełnosprawności i Upośledzeń wyodrębniając trzy (co prawda ściśle ze sobą powiązane i wzajemnie uwarunkowane) wymiary niepełnosprawności: uszkodzenie narządów organizmu, niepełnosprawność biologiczna lub funkcjonalna organizmu, upośledzenie lub niepełnosprawność społeczna (która może występować w formie utrudnień, ograniczeń i uniemożliwień), podejmuje próbę interpretacyjnego, a co za tym idzie również działaniowego, przeniesienia odpowiedzialności za uzyskany/uzyskiwany przez osobę niepełnosprawną poziom fizycznego i psychospołecznego funkcjonowania na element zewnątrzpochodny, a zasadniczo wsparcia udzielanego osobie niepełnosprawnej przez środowiska jej codziennej egzystencji oraz instytucje, które owo wsparcie winny okazywać i realizować. Bowiem uszkodzenie, oznaczające wszelki brak lub anormalność psychologicznej, fizjologicznej lub anatomicznej struktury lub funkcji organizmu na skutek określonej wady wrodzonej, choroby lub urazu może (aczkolwiek nie musi) wywoływać stan niepełnosprawności biologicznej, rozumianej jako ograniczenie lub brak (wynikający z uszkodzenia) zdolności do wykonywania czynności w sposób i w zakresie uważanym za normalny dla człowieka, a uszkodzenie 
w powiązaniu z niepełnosprawnością biologiczną może (chociaż przecież nie musi) doprowadzać do upośledzenia, czyli niepełnosprawności społecznej rozumianej jako mniej korzystna sytuacja osoby niepełnosprawnej, wynikająca z uszkodzenia lub niepełnosprawności, która ogranicza lub uniemożliwia wypełnianie ról związanych z jej wiekiem, płcią oraz sytuacją społeczną i kulturową (Majewski, 1999, s. 131-134).

Oczywiste jest, że podana sytuacja przenosi percepcję oraz recepcję indywidualną i ogólnospołeczną sytuacji/stanu niepełnosprawności człowieka na wątki funkcjonalno-egzystencjalne, co niewątpliwie należy identyfikować $\mathrm{w}$ kategoriach pozytywnych, $\mathrm{z}$ drugiej strony jednak podejmuje próbę ukrycia, zamazania wątków biologicznych czy, delikatniej rzecz ujmując, kontekstowego ukrycia tych wątków - co można postrzegać w kategoriach niekoniecznie jednoznacznie pozytywnych.

Jeszcze dalej idzie wprowadzona w roku 2001 przez Światową Organizację Zdrowia Międzynarodowa Klasyfikacja Funkcjonowania, Niepełnosprawności i Zdrowia (ICF), przyjęta pod wpływem krytyki przyjętej w 1980 r. Międzynarodowej Klasyfikacji Uszkodzeń, Niepełnosprawności i Upośledzeń jako zbytnio akcentującej aspekt medyczny ludzkiej niepełnosprawności. Ujmuje bowiem wzajemne relacje między zdrowiem, funkcjonowaniem i niepełnosprawnością organizmu, a także uczestnictwem człowieka w życiu społecznym. Przyjmuje więc bio-psycho-społeczny model niepełnosprawności i nie ogranicza się tylko do wymiaru biologicznego (medycznego) tego stanu. Wychodząc z założenia, że:

1) człowiek jest istotą biologiczną; stanowi ją organizm człowieka o określonej strukturze i wypełniający określone funkcje - funkcjonowanie organizmu;

2) człowiek jest określoną osobą, działającą i wypełniającą określone czynności i zadania życiowe - istotą aktywną;

3) człowiek jest członkiem określonej grupy społecznej, do której przynależy i w życiu której uczestniczy - funkcjonowanie społeczne, tzn. funkcjonuje na trzech poziomach: biologicznym, indywidualnym (jednostkowym) i społecznym, nie tylko wskazuje wymiary niepełnosprawności: biologiczny, indywidualny i społeczny, ale także poziomy (formy) tego stanu:

- biologiczny (zniesienie, ograniczenie lub zaburzenie przebiegu funkcji organizmu w zależności od stopnia i zakresu uszkodzenia jego organów lub układów),

- indywidualny (jednostkowy) lub osobowy - to ograniczenie aktywności, 
- społeczny - ograniczenie uczestnictwa w życiu społecznym - funkcjonowania społecznego, szczególne znaczenie nadaje czynnikom kontekstowym, tj. środowiskowym i indywidualnym (cechy osobiste) (Międzynarodowa Klasyfikacja Funkcjonowania, Niepełnosprawności i zdrowia, 2007).

I w tym miejscu zauważamy, podobnie jak przy koncepcji poprzedniej, koncentrację na wymiarach psychospołecznych (co pozytywne) i minimalizację wymiaru biologicznego (co już jest niekoniecznie pozytywne) szeroko ujmowanego stanu niepełnosprawności osoby ludzkiej.

Wymiernym rezultatem przeanalizowanych koncepcji są proponowane ujęcia najistotniejszych w rozważaniach nad stanem niepełnosprawności terminów: „zdrowie”, „choroba”, „niepełnosprawność”, „osoba niepełnosprawna”.

Jeszcze w okresie, kiedy podstawą do realizacji analizy stanu ludzkiej niepełnosprawności była Międzynarodowa Klasyfikacja Uszkodzeń, Niepełnosprawności i Upośledzeń, Światowa Organizacja Zdrowia (WHO) definiowała pojęcie zdrowia jako: stan pełnego, dobrego samopoczucia fizycznego, psychicznego i socjalnego, tj. jako stan, w którym budowa i czynności wszystkich tkanek i narządów są nie tylko prawidłowe, ale zapewniają również wewnętrzną równowagę i zdolność przystosowania się do otaczających warunków, w tym również społecznych. Oznaczało to, że każdy stan wykraczający poza wyżej wymieniony jest chorobą (Śródka, 1995, s. 274). Natomiast chorobę definiowano jako „stan dynamiczny organizmu, w którym dochodzi do nieprawidłowej reakcji układów lub narządów na bodźce środowiska zewnętrznego lub wewnętrznego. Stan taki może doprowadzić do zmian anatomicznych w określonych narządach lub do zakłóceń w mechanizmach regulacyjnych. Nie ogranicza się on tylko do zmian miejscowych, lecz powoduje zawsze zmiany czynnościowe całego ustroju" (Śródka, 1995, s. 276).

Na podstawie podanych treści definicyjno-interpretacyjnych omawianych określeń można wnioskować, z jednej strony, że mamy do czynienia ze swoistym interpretacyjnym rozluźnieniem w definiowaniu pojęć zdrowia i choroby, polegającym na uwzględnieniu wpływów zewnątrzpochodnych (np. socjalnych), z drugiej strony jednak należy odnotować warunek obecności zmian wewnętrznych w organizmie ludzkim w postaci obecnych nieprawidłowości w reakcji układów lub narządów, co pozwala na niepostrzeganie każdego stanu odbiegającego od przyjętych standardów normy za stan chorobowy. Wydaje się to niewątpliwym sukcesem takiej właśnie interpretacji, bowiem ogranicza możliwości niedointerpretacji lub nadinterpretacji sytuacji uznawanych za stan zdrowia lub choroby organizmu ludzkiego. 
Niestety, tak mi się wydaje, o wiele większe pole dla zamazywania, rozpływalności w treściowym, kontekstowym interpretowaniu pojęcia „zdrowie” daje ujęcie tego określenia przyjęte w Międzynarodowej Klasyfikacji Funkcjonowania, Niepełnosprawności i Zdrowia (ICF), gdzie „zdrowie” oznacza: dobrostan (dobre samopoczucie), obejmujący całokształt dziedzin życia ludzkiego wraz z fizycznymi, psychicznymi i społecznymi aspektami włącznie, które tworzą to, co nazywa się „dobrym życiem”. Nieposiadanie bowiem tego, co się nazywa „dobrym życiem” może oznaczać chorobę. Ponadto wątpliwości budzi interpretacja innego ważnego dla danej koncepcji określenia na funkcjonowanie człowieka, które zależąc od stanu zdrowia, obejmuje kilka istotnych składników na owo funkcjonowanie człowieka składających się, tj.: funkcjonowanie organizmu, aktywność człowieka oraz jego uczestnictwo w życiu społecznym. Pojęcie to oznacza więc pozytywne aspekty wzajemnych relacji pomiędzy osobą z określonym stanem zdrowia a czynnikami wypływającymi z kontekstu (sytuacji), w którym znajduje się osoba ludzka. Konkretnie chodzi o czynniki środowiskowe i cechy osobowe, które mają wpływ na dobre funkcjonowanie człowieka (Majewski, 1999, s. 131-134). Na podstawie przywołanych treści można odnieść wrażenie, że mamy do czynienia z mało konkretnym i niejasnym powiązaniem (a to tworzy przyjazny grunt do generalizacji i ogólnikowości) stanu zdrowia, choroby oraz wynikającego ze zdrowia i choroby funkcjonowania człowieka z zasadniczo dominującą ich percepcją jako wynikających z kontekstów psychospołecznych.

Egzemplifikacją opisanego podejścia jest, a właściwie są, definicje osoby niepełnosprawnej i niepełnosprawności oraz postrzeganie różnych sytuacji i zjawisk indywidualnych i społecznych jako choroby (np. społecznej lub cywilizacyjnej). I tak, za propozycją podaną w Międzynarodowej Klasyfikacji Funkcjonowania, Niepełnosprawności i Zdrowia (ICF) niepełnosprawność definiowana jest jako: utrudnienie, ograniczenie lub uniemożliwienie aktywności człowieka i jego uczestnictwa w życiu społecznym (Majewski, 1999, s. 131-134). Określa wobec powyższego negatywne aspekty interakcji pomiędzy człowiekiem a czynnikami wypływającymi z kontekstu, w którym znajduje się człowiek, (nie)dookreślając równocześnie elementy związane z funkcjonowaniem jego organizmu w korelacie zdrowia lub choroby i eksponując kwestie aktywności i uczestnictwa w życiu społecznym. Natomiast definicja osoby niepełnosprawnej według Europejskiego Forum Niepełnosprawnych brzmi: „Osobą niepełnosprawną jest jednostka w pełni swych praw, znajdująca się w sytuacji upośledzającej ją na skutek barier środowiskowych, ekonomicznych i społecznych, których z powodu występujących u niej uszkodzeń nie możne przezwyciężyć 
w taki sposób, jak inni ludzie. Bariery te zbyt często są zwiększane przez deprecjonujące postawy ze strony społeczeństwa"(Kotowski, 2008, s. 210). A także w Konwencji ONZ o prawach osób niepetnosprawnych z 2006 i w Europejskiej strategii w sprawie niepetnosprawności 2010-2020: Odnowione zobowiazanie do budowania Europy bez barier: do osób niepełnosprawnych zaliczają się te osoby, które mają długotrwałe fizyczne, umysłowe, intelektualne lub dotyczące zmysłów uszkodzenia mogące, $\mathrm{w}$ oddziaływaniu z różnymi barierami, utrudniać im pełne i skuteczne uczestnictwo w społeczeństwie, na zasadach równości z innymi osobami (Dz. U. z 2012, poz. 1169, s. 3).

Podobna zresztą sytuacja ma miejsce we wcześniejszych ujęciach osoby niepełnosprawnej i niepełnosprawności powstałych jeszcze pod wpływem idei zawartych w Międzynarodowej Klasyfikacji Uszkodzeń, Niepełnosprawności i Upośledzeń. Jako przykładową można przywołać definicję obecną w Uchwale Sejmu RP z 1 sierpnia 1997 r. „Karta Praw Osób Niepełnosprawnych”: „Niepełnosprawne są osoby, których sprawność fizyczna, psychiczna lub umysłowa trwale lub okresowo utrudnia, ogranicza lub uniemożliwia życie codzienne, naukę, pracę oraz pełnienie ról społecznych, zgodnie z normami prawnymi i zwyczajowymi" (Monitor Polski, nr 50, poz. 474 i 475, 1997, s. 970).

Pomijam w tym miejscu kontrowersje związane z rozgraniczaniem sprawności psychicznej i umysłowej, jako dwóch odrębnych sprawności. Także ujęcie osób niepełnosprawnych podane w Ustawie z 27 sierpnia 1997 r. o rehabilitacji społecznej i zawodowej oraz zatrudnianiu osób niepełnosprawnych: „Niepełnosprawnymi są osoby, których stan fizyczny, psychiczny lub umysłowy trwale lub okresowo utrudnia, ogranicza lub uniemożliwia wypełnianie ról społecznych, a w szczególności ogranicza zdolność do wykonywania pracy zawodowej, jeżeli uzyskały orzeczenie o zakwalifikowaniu do jednego z trzech stopni niepełnosprawności albo orzeczenie o całkowitej lub częściowej niezdolności do pracy, a jeżeli nie ukończyły 16 roku życia - orzeczenie o rodzaju i stopniu niepełnosprawności” (Dz. U, Nr 123, poz. 776, 1997, s. 3736).

Poza zasygnalizowanymi wyżej konsekwencjami niejednoznacznej i zamazanej nadinterpretacji sytuacji/stanu zdrowia i choroby jest przenoszenie tych określeń na zjawiska społeczne, np. na zjawisko alkoholizmu, narkomanii, ubóstwa, bezdomności, znieczulicy społecznej, społecznego niedostosowania, niewydolności wychowawczej rodziny, wyalienowania, eurosieroctwa itd. Konsekwencją niedointerpretacji zaś jest identyfikacja niepełnosprawności $\mathrm{z}$ chorobą przejawiająca się między innymi w stosowaniu (nawet przez naukę i naukowców) jako przeciwstawnych sformułowań osoba/dziecko zdrowa/ zdrowe i osoba/dziecko pełnosprawna/pełnosprawne. 
Stąd na gruncie nauk medycznych prowadzone są obecnie starania, aby zweryfikować istniejącą definicję choroby z nacelowaniem na większą jej konkretyzację i głębsze uszczegółowienie. Proponuje się miedzy innymi wprowadzenie następującej definicji terminu „choroba”: choroba jest takim stanem organizmu, kiedy to czujemy się źle, a owego złego samopoczucia nie można jednak powiązać z krótkotrwałym, przejściowym uwarunkowaniem psychologicznym lub bytowym, lecz z dolegliwościami wywołanymi przez zmiany strukturalne lub zmienioną czynność organizmu. Przez dolegliwości rozumiemy przy tym doznania, które są przejawem nieprawidłowych zmian struktury organizmu lub zaburzeń regulacji funkcji narządów (International Statistical Classification of Diseases and Related Health Problems - 10th, Revision Version for 2007).

\section{Pozoranctwo/pozorność/pozory/pozór w płaszczyźnie faktycznie realizowanych działań specjalistycznych na rzecz osób niepełnosprawnych}

Kolejną znaczącą kwestią dla dyskursu na temat pozoranctwa w działaniach na rzecz osób niepełnosprawnych, z uwzględnieniem korelatu pozorności, pozorów oraz pozoru jest obszar działań specjalistycznych adresowanych do omawianej grupy ich odbiorców, obecnie dość często nazwanych beneficjentami. Szczególnie chodzi o działania związane z: 1) terapią, 2) edukacją, 3) realizacja, potrzeb, 4) wsparciem i pomocą społeczna, 5) dostępem do pracy, instytucji społecznych, dóbr kultury oraz sportu i rekreacji, a także o podejście do ujmowania istoty znaczących dla działań specjalnych paradygmatów i postulatów, takich miedzy innymi jak: habilitacja/rehabilitacja, równość/identyczność praw, maksymalne usprawnianie niezaburzonych/nieuszkodzonych lub najmniej zaburzonych/najmniej uszkodzonych sfer fizycznych i/lub psychicznych.

Analizując zagadnienie pozoranctwa w przełożeniu na problematykę terapii, warto zasygnalizować wątek kontekstowy oraz działaniowy lub, inaczej mówiąc, behawioralny. Wątek kontekstowy dotyczy zasadniczo nadinterpretacji istoty działań terapeutycznych (leczniczych) pod adresem osób niepełnosprawnych. Polega na przekraczaniu granic w dostrzeganiu elementów leczniczych (terapeutycznych) w czynnościach, które są naturalne, normalne dla osób pełnosprawnych i są niesłusznie uznawane/identyfikowane jako terapeutyczne wobec osób niepełnosprawnych, tylko dlatego, że ich adresatem są takie właśnie osoby lub dlatego, że realizacja tych czynności odbywa się w sposób bardziej lub mniej zaplanowany i bardziej lub mniej celowo zorganizowany. Wy- 
miernym efektem takich tendencji jest poczytywanie za działania terapeutyczne tych, które nimi być raczej nie powinny, np. kwestia aktywizacji osób niepełnosprawnych za pomocą pracy (ergoterapia), czytelnictwa (literaturoterapia), kontraktu z filmem (filmoterapia), teatrem (teatroterapia) fotografowania (fototerapia), pracy w ogrodzie (ogrodoterapia), a nawet w określonych warunkach i sytuacjach, tzw. zooterapia i inne. Kontekst niedointerpetacji natomiast obejmuje brak dostrzegania czynnika leczniczego lub bagatelizowania tego czynnika w działaniach/czynnościach, które taki czynnik faktycznie posiadaja, np. w rzeczywistej terapii medycznej (farmakoterapii, terapii chirurgicznej, fizykoterapii) czy psychologicznej (psychoterapii). Wątek działaniowy - behawioralny z kolei to realizacja czynności niesłusznie percypowanych jako terapeutyczne i związane z nim ukierunkowanie na określanie i poszukiwanie czynnika terapeutycznego w czynnościach, które są zwyczajne/zwykłe i normalne dla istot ludzkich tylko z tego powodu, że odnoszą się do osoby niepełnosprawnej.

Pozoranctwo w obszarze edukacji, z uwzględnieniem możliwości jego przyłożenia na perspektywę pozorności, pozorów oraz pozoru dotyczyć może wymiaru organizacyjno-realizacyjnego oraz koncepcyjno-mentalnościowego wszelakich działań obejmujących kształcenie osób z niepełnosprawnością. Wymiar organizacyjno-realizacyjny to między innymi werbalna artykulacja, wizualne poparcie, a nawet poparcie prawno-legislacyjne (w postaci istniejącego prawa oświatowego) dla tendencji i idei kształcenia integracyjnego czy inkluzyjnego, bez rzeczywistego przygotowania placówek ogólnodostępnych do kształcenia uczniów niepełnosprawnych zarówno w kwestii dostosowania treści, metod, form i warunków kształcenia do indywidualnych możliwości takich uczniów, jak i przygotowania kadry pedagogicznej do pracy z uczniem niepełnosprawnym. Dotyczy to między innymi koncentracji na dokształceniu kadry już pracującej w szkolnictwie ogólnodostępnym w postaci form kursowo-warsztatowych budzących poważne wątpliwości jakościowo-merytoryczne i organizacyjno-lokalizacyjne, w instytucjach organizujących i realizujących dokształcanie nauczycieli szkół ogólnodostępnych do pracy z uczniem niepełnosprawnym niemających często żadnego związku z zagadnieniami niepełnosprawności.

To także, jeśli nawet uczeń niepełnosprawny realizuje obowiązek szkolny kształcąc się wspólnie z pełnosprawnymi rówieśnikami, nieadekwatne ocenianie jego postępów edukacyjnych i rozwojowych w postaci oceny zaniżonej (powstającej zasadniczo jako rezultat porównania z postępami uczniów pełnosprawnych) lub zawyżonej (przy gloryfikacji faktu niepełnosprawności lub usprawiedliwianiu niepełnosprawnością braku albo ograniczonych osiągnięć 
edukacyjnych). Ponadto proponowanie uczniom niepełnosprawnych, w ramach przysługującej im pomocy psychologiczno-pedagogicznej, form standardowych z tzw. klucza, tych obecnych na terenie szkół ogólnodostępnych (np. zajęć korekcyjno-kompensacyjnych, logopedycznych) bez uwzględnienie istoty, stopnia i charakteru niepełnosprawności oraz indywidualnych potrzeb.

Przykładem może być sytuacja dotycząca dzieci z mózgowym porażeniem dziecięcym (MPD), zamieszkujących w dużych miejscowościach i trafiających do oddziałów przedszkolnych w szkolnictwie ogólnodostępnym. Zasadniczo, dzięki wczesnej diagnostyce i wczesnej rehabilitacji MPD, są to dzieci stosunkowo wysoko funkcjonujące i dość dobrze zrehabilitowane, jak na ich trudności ruchowe i neurologiczne. A jeśli są to dzieci 5-6-letnie, to ponadto korzystaja z obowiązujących w naszym kraju przepisów podanych w Rozporzqdzenie Ministra Edukacji Narodowej z dnia 3 lutego 2009 r. w sprawie organizowania wczesnego wspomagania rozwoju dzieci (Dz. U. Nr 23, 2009). Mają więc zapewnioną dodatkową pomoc psychologiczno-pedagogiczną, także w formie terapii logopedycznej, realizowaną na terenie szkoły ogólnodostępnej. Poza tym są to dzieci, które korzystały już, na ogół w ramach usług specjalistycznych oferowanych w strukturach opieki zdrowotnej, $\mathrm{z}$ różnych form wspomagania rozwoju, także z opieki logopedycznej. Część z nich z powodu wielu lat pracy specjalistycznej, również logopedycznej, w szkole podstawowej szczególnego wsparcia logopedycznego tak naprawdę już nie potrzebuje. Prezentują bowiem poziom funkcjonowania komunikacyjnego porównywalny z pełnosprawnymi rówieśnikami. Jednak ze względu na orzeczenie o potrzebie wczesnego wspomagania i stereotypowe podejście do kwestii możliwych form zajęć specjalistycznych, realizowanych w ramach wczesnej rehabilitacji, polegających na zaleceniu zajęć najbardziej tradycyjnych, bez zastanowienia, czy są one potrzebne, czy nie, posiada wpis o konieczności realizacji terapii logopedycznej. U analizowanych dzieci, jako konsekwencja udziału od najwcześniejszego chwil życia w różnych formach specjalistycznego wspomagania rozwoju, koncentracji specjalistów i rodziny na dziecku i nierzadko nadopiekuńczych postaw, pojawiają się problemy natury socjalizacyjnej i psychologicznej. Zasadniczo chodzi o to, że wiele z nich prezentuje zachowania i postawy egocentryczne, trudności w nawiązywaniu relacji z rówieśnikami, narzuca im swoje propozycje i oczekiwania, pragnie dominować i dyscyplinować rówieśników pod kątem własnych potrzeb, ma trudności z respektowaniem zasad postępowania obowiązujących wśród rówieśników, w podporządkowywaniu się normom grupowym, a także poleceniom dorosłych. Stąd zasadniczo dzieci takie w większym stopniu potrzebują nie tyle pomocy logopedycznej, ile socjo- oraz 
psychoterapeutycznej, jak również zajęć stymulujących ich rozwój ogólny, tj. zajęć określanych jako ogólnorozwojowe.

Pozoranctwo w obszarze edukacji uczniów niepełnosprawnych w wymiarze koncepcyjno-mentalnościowym egzemplifikuje się w lokowaniu istoty kształcenia opisywanej grupy uczniów w konwencji specjalnych potrzeb edukacyjnych, zapominając jednocześnie, że generalnie potrzeby takich uczniów (w tym edukacyjne) są identyczne jak ich pełnosprawnych rówieśników. Jeśli natomiast mówimy o jakiejkolwiek specjalności (a już samo mówienie o specjalności można traktować w kategoriach stygmatu), to dotyczy ona przede wszystkim kwestii stricte organizacyjnych, a więc zakresu, metod, form, środków i warunków realizacji potrzeb edukacyjnych ucznia z niepełnosprawnościa.

Innym zagadnieniem obejmującym sferę pozoranctwa $\mathrm{w}$ działaniach na rzecz osób niepełnosprawnych, z uwzględnieniem aspektu ich pozorności, pozorów oraz pozoru, jest dylemat realizacji potrzeb. Zdaje się, że obecnie ma on zewnątrzpochodne, społeczne ukierunkowanie, polegające na nacelowaniu na organizację wielokroć jakościowo, jak również ilościowo wątpliwej pomocy instytucjonalnej oraz na przełożeniu koncentracji pomocy dotyczącej realizacji potrzeb osób niepełnosprawnych na obszar instytucjonalny, przy równoczesnej minimalizacji znaczenia pomocy ze strony środowiska rodzinnego. Oznacza to, że możliwe środki finansowe, które są zresztą ograniczone, kierowane są pod adresem instytucji, a nie środowiska, które może i powinno w realizacji potrzeb osoby niepełnosprawnej odgrywać rolę dominująca. Dodatkowo można zwrócić uwagę na sprawę istniejącej maksymalizacji postulatu realizacji potrzeb społecznych, z równoczesnym marginalizowaniem znaczenia realizacji potrzeb biologicznych, egzystencjalnych osoby niepełnosprawnej.

Kolejnym problemem korespondującym z pozoranctwem w działaniach wobec osób niepełnosprawnych w kontekście ich pozorności, pozorów oraz pozoru jest dostęp do pracy, instytucji społecznych, dóbr kultury oraz sportu i rekreacji. Polega między innymi na nieuzasadnionym i pozbawionym zdroworozsądkowego podejścia do promowania inicjatyw bezkrytycznie postulujących pełne dostosowanie, pełną dostępność, maksymalne otwarcie na osoby niepełnosprawne na zasadach identycznych jak dla osób pełnosprawnych. Wymiernym rezultatem wskazanego podejścia są możliwe nadużycia, a jeśli nie nadużycia, to cyniczne i bezkarne wykorzystanie środków przeznaczanych na aktywizację zawodową, społeczną, kulturalną oraz rekreacyjno-sportową osób niepełnosprawnych. Są to pozorowane projekty aktywizacji zawodowej proponujące teoretyczne, a nawet praktyczne szkolenia, bez wizji uzyskania zatrudnienia. To organizacja turnusów rehabilitacyjnych w wyznaczonych, posiada- 
jących certyfikację (w różny sposób uzyskaną) ośrodkach wypoczynkowych, często jakoby dostosowanych do potrzeb osób niepełnosprawnych, za pieniądze z puli przeznaczonej dla tych osób, bez rozróżnienia na osoby doświadczające skutków niepełnosprawności od urodzenia, wczesnego dzieciństwa czy okresu dorosłości oraz na osoby, które na skutek naturalnego starzenia się organizmu zmagają się z trudnościami zdrowotno-sprawnościowymi, wynikającymi z ich wieku. To także adaptacja, a właściwie pseudoadaptacja możliwości korzystania przez określone kategorie osób niepełnosprawnych z kin, teatrów czy muzeów. Wprowadzony opis słowny tego, co się dzieje na oglądanym przez osobę niewidzącą od urodzenia lub wczesnego dzieciństwa filmie, spektaklu teatralnym lub tego, co przedstawia oglądany przez taką osobę obraz Leonarda da Vinci czy Francisco Goi zdaje się graniczyć z absurdem. Wyobrażenia takiej osoby bowiem mają zupełnie odmienny charakter, inną istotę i konstrukcję. Są zasadniczo zbudowane $\mathrm{z}$ wyobrażeń pozawizualnych, z dominacją aktywizacji innych zmysłów i wyobraźni - również pozawizualnej. Pomijam w tym miejscu, aczkolwiek sygnalizuję jako problem, działania dotyczące zdobywania Mount Everestu, Mount Blanc czy Kilimandżaro.

Określone przejawy pozoranctwa obecne są też w założeniach oraz postulatach artykułowanych przez teorię, a zatem praktykę współczesnej pedagogiki specjalnej w Polsce. Wśród nich niewątpliwie wymienić można brak jednoznacznego i utrwalonego w mentalności oraz zalecanych działaniach specjalistycznych odniesienia obecnego w światowych unormowaniach prawnych (Dz. U. z 2012, poz. 1169; Europejska strategia w sprawie niepełnosprawności 2010-2020: Odnowione zobowiązanie do budowania Europy bez barier, 2010) do sytuacji, kiedy mamy do czynienia z działaniami ujmowanymi jako habilitacyjne (dotyczą osób z niepełnosprawnością od urodzenia lub wczesnego dzieciństwa), a kiedy z działaniami rehabilitacyjnymi (dotyczą osób z niepełnosprawnością nabywaną w okresie rozwojowym, w późniejszym okresie życia). Także w jakimś sensie postulowanie potrzeby maksymalnej koncentracji w pracy specjalistycznej z osobą niepełnosprawną na niezaburzonych/nieuszkodzonych lub najmniej zaburzonych sferach fizycznych i psychicznych, czasami graniczące z gloryfikacją i niezauważaniem potrzeby usprawniania najbardziej uszkodzonych/najbardziej zaburzonych układów, czynności i funkcji. Nie jest bowiem wyjątkową sztuką aktywizowanie czegoś najmniej niezaburzonego, ale bezdyskusyjnie sztuką taką jest aktywizacja tego, co uległo zaburzeniu w stopniu utrudniającym rozwój oraz fizyczne i psychospołeczne funkcjonowania człowieka.

$\mathrm{W}$ dyskursie nad problematyką pozoranctwa w działaniach adresowanych do osób niepełnosprawnych pozostaje jeszcze kwestia postulatu identyczności ich 
praw oraz rozwiązań dotyczących przygotowania nowych, młodych specjalistów do pracy z osobami niepełnosprawnymi. Reasumując krótko podane dylematy, stosowne wydaje się podkreślenie, że w praktyce oraz w aplikacji na możliwości osób niepełnosprawnych postulowanie równości ich praw w konfrontacji z równością praw osób pełnosprawnych stawia osoby niepełnosprawne w sytuacji nierówności szans, oczekiwania na przegraną w okolicznościach konkurowania z pełnosprawnymi na zasadach identyczności stawianych wymogów i pożądanych efektów wobec realizowanych przez te dwie grupy osób aktywności.

Natomiast kwestia przygotowania specjalistów do pracy z osobami niepełnosprawnymi w przełożeniu na wymiar pozoranctwa dotyczy możliwości kształcenia studentów, a w przyszłości specjalistów z takimi osobami pracujących, przez nauczycieli akademickich, którzy nigdy nie pracowali z ludźmi niepełnosprawnymi, lub jeśli pracowali, to wiele lat wstecz i obecnie nie posiadaja adekwatnej oceny rzeczywistości obecnej w tym obszarze. Postrzegają bowiem aktualne działania realizowane wobec osób niepełnosprawnych przez pryzmat czasów minionych, bez uwzględnienia lub z fragmentarycznym uwzględnieniem zmian, które się w tych działaniach dokonały. Ponadto częstokroć, z racji sytuacji szkolnictwa wyższego, są to nauczyciele skupiający swoją aktywność zawodową na kontekście ilościowym, na uzyskiwaniu wymaganej liczby punktów za realizowaną działalność naukową, publikacyjna, konferencyjną oraz (wy)standaryzowaniu swoich postaw, zachowań i dążności na cele formalne, $\mathrm{z}$ równoczesną dekoncentracją na etosie nauki, naukowości i naukowo-zawodowego powołania.

\section{Podsumowanie}

Podsumowując dyskurs na temat pozoranctwa w działaniach na rzecz osób niepełnosprawnych w powiązaniu z kwestią pozorności, pozorów i pozoru oraz z wybranymi jego aspektami i kontekstami, można wskazać kilka problemów nadrzędnych i postawić określone pytania o jego sedno, profilaktykę, obecność, konsekwencje czy możliwości ograniczania ewentualnych skutków. Udzielenie odpowiedzi na pytanie o profilaktykę pozoranctwa jest sprawą niezwykle trudną, a w pewnych zakresach nawet wręcz niemożliwą, bowiem jest to przede wszystkim pytanie filozoficzne o istotę natury ludzkiej i ludzkich zachowań, sięgające w głąb ograniczoności, niedoskonałości i nieprzewidywalności ludzkiego bytu. Udzielenie odpowiedzi na pytanie o obecność pozoranctwa jest już znacznie prostsze. Zamyka się zasadniczo w konkluzji, że było, jest i prawdopodobnie będzie, dopóki będzie istniała ludzkość. Na pytanie o jego konse- 
kwencje również: są nimi brak prawdy, fałsz, zakłamanie, oszukiwanie i obłuda. Na pytanie o możliwości ograniczania skutków pozoranctwa odpowiedź jest co najmniej dwuwariantowa. Może ono być determinowane sytuacją społeczno-zawodową ludzi, wielekroć od nich niezależną, wymuszającą pozorowanie zachowań oraz realizowanych działań zawodowych. Może też zależeć od przyjętego przez konkretną osobę systemu wartości, indywidualnej postawy wobec pozoranctwa, akceptacji dla jego obecności i przyzwolenia na jego istnienie. Podejmując więc działania na rzecz likwidacji pozoranctwa lub minimalizacji jego skutków, musimy zdawać sobie sprawę z tego, że często będziemy działać przeciwko innym. Natomiast podejmując działania na rzecz jego akceptacji, będziemy, czy chcemy tego czy nie, działać przeciwko samym sobie. Stąd podejście konkretnego człowieka do problematyki pozoranctwa w życiu własnym i w otoczeniu pozostaje sprawą indywidualnego wyboru, indywidualnej odpowiedzialności za dokonany wybór i ponoszenia konsekwencji podjętej przez siebie decyzji w płaszczyźnie osobowej, społecznej oraz w korelacie historycznej odpowiedzialności przed pokoleniami przyszłymi.

\section{Bibliografia}

Europejska strategia w sprawie niepetnosprawności 2010-2020: Odnowione zobowiazanie do budowania Europy bez barier, Bruksela 15.11.2010.

International Statistical Classification of Diseases and Related Health Problems - 10th, Revision Version for 2007, http://www.who.int/classifications/icd/en, dostęp: $02.04 .2014 \mathrm{r}$.

Karta Praw Osób Niepetnosprawnych, Uchwała Sejmu Rzeczypospolitej Polskiej z dnia 1 sierpnia 1997 r., Monitor Polski, nr 50, poz. 474 i 475.

Konwencja o prawach osób niepetnosprawnych, ONZ, Nowy Jork 2006, Dz. U. z 2012, poz. 1169.

Kotowski S. (2008), Przewodnik po problematyce osób niewidomych i słabo widzacych, Fundacja Trakt, Warszawa.

Majewski T. (1999), Biopsychospołeczna koncepcja niepetnosprawności, „Szkoła Specjalna”, nr 3, s. 131-134.

Międzynarodowa Klasyfikacja Funkcjonowania, Niepetnosprawności i zdrowia (ICF) oraz jej zastosowanie. Materiały robocze na CD, Centrum Systemów Informacyjnych Ochrony Zdrowia, Warszawa 8.10.2007.

Rochefoucauld F. de La (1951), Maksymy i rozważania moralne, Zakład Narodowy im. Ossolińskich, Warszawa. 
METAANALIZY BADAŃ EDUKACYJNYCH

Rozporzqdzenie Ministra Edukacji Narodowej z dnia 3 lutego 2009 r. w sprawie organizowania wczesnego wspomagania rozwoju dzieci, Dz.U. 2009, Nr 23, poz. 133.

Szymczak M. (red.) (1979), Słownik języka polskiego, t. II: L-P, PWN, Warszawa.

Śródka A. (1995), Co to jest choroba, [w:] W. S. Gomułka, W. Rewerski (red.), Encyklopedia zdrowia, t. I, WN PWN, Warszawa.

Tokarski J. (red.) (1978), Stownik wyrazów obcych, PWN, Warszawa.

Ustawa z 27 sierpnia 1997 r. o rehabilitacji spolecznej i zawodowej oraz zatrudnianiu osób niepetnosprawnych, Dz.U. 1997, nr 123, poz. 776. 